\title{
Influence of Age and Gender on Asymptomatic Carotid Disease
}

\section{ABSTRACT}

Introduction: Stroke is one of the most severe and the most common diseases of modern man. Prevention is necessary in order to detect people who have risk factors for it.

Objective: To determine the frequency of asymptomatic carotid disease in people of different ages.

Subjects and methods: The project encompassed the part of population, that is, groups at high risk for stroke from the Republic of Srpska. 20240 patients were examined - there were 12797 (63.23\%) females and 7443 (36.77\%) males.

The study protocol was created, as well as adequate software products to support all phases of project implementation such as preparation of marketing materials, doctors' appointments, building of application for doctors and nurses to record patients' data, reports, analysis and conclusion. Upon completion of the project, data were statistically processed and the analysis of obtained results was conducted.

Discussion: Pathological changes in blood vessels were noticed through the ultrasound examination of the aforementioned blood vessels of the neck and head, and the degree of narrowing of the blood vessels was determined. Furthermore, adequate measures and treatment to prevent progression of the aforementioned as well as the occurrence of stroke were applied. On the basis of the obtained data, it was concluded that the age was one of the most significant predisposing factors for the development of asymptomatic carotid disease. It was also noted that females were, more than men, prone to developing carotid asymptomatic disease.

Conclusion: Average stenosis of all respondents was 18.36\% (in females, stenosis was approximately $3.92 \%$ lower and it was $16.92 \%$, when compared to males $20.84 \%$ ). Overall median was 16\% (in females 15\% and it was 5\% lower than in men $-20 \%)$.

Keywords: ultrasound of the blood vessels of the neck and head, prevention, age, gender 


\section{Introduction}

Stroke is one of the most difficult and the most common diseases of modern man and it is the cause of death in over 4.5 million people. Due to the consequences of the stroke (the third cause of mortality and the first cause of disability of modern man), it is very important to prevent the occurrence of the one. ${ }^{1}$ Due to the prevention, detection of people who have risk factors for stroke (high blood pressure, diabetes, heart disease, high blood lipids, smokers, obese people, people whose family members had a stroke, and people exposed to stress) is required, as well as detection of pathological changes in the blood vessels of the head and neck which by treating them, can lead to preventing the occurrence of the stroke. ${ }^{2-7}$

Approximately $40-60 \%$ of strokes occur due to pathological changes in the blood vessels of the head and neck, ${ }^{8}$ and therefore, an early detection and beforehand treatment of the same is necessary. The aforementioned changes can be detected by auscultation of blood vessels, ultrasound examination, CT angiography, NMR angiography, and conventional angiography. Taking into consideration the advantages and disadvantages of the aforementioned diagnostic methods, ultrasound examination of blood vessels, by its characteristics, is considered to be "the method of choice"..$^{-11}$

Ultrasound examination of blood vessels is of high importance in detection of asymptomatic carotid disease which implies a state in which pathological changes in blood vessels are expressed while subjective obstructions and neurologic disorders are absent. ${ }^{12,13}$ The annual risk of stroke ranges from 2 to $5 \%$ for patients with significant asymptomatic carotid lumen stenosis (greater than 70\%).14,15 Early detection of patients with asymptomatic carotid stenosis allows the application of carotid endarterectomy and carotid stenting. ${ }^{16}$ According to various authors, data on the prevalence of asymptomatic carotid occlusive disease vary. High-grade asymptomatic carotid stenosis causes a disturbance in cognitive functioning of the patient. In the study conducted by Balestrini, 210 patients who had high-grade stenosis were examined. The study results showed that the high-grade carotid artery, although in its asymptomatic phase, caused increased level of cognitive deterioration. ${ }^{17-21}$

In the Republic of Srpska there is a large number of people with commonly called risk factors for stroke and they are not in the position to do the ultrasonic testing. This project enabled the residents to have a chargeless and fast ultrasound screening of the blood vessels of the neck and head, and therefore, the prevention of stroke.

\section{Aim}

The aim of this study is to detect pathological changes in the blood vessels of the head and neck and to prevent stroke in people who have risk factors for it (high blood pressure, diabetes, heart disease, high blood lipids, smokers, obese people, people whose family members had a stroke, and people exposed to stress), i.e. to determine the frequency of asymptomatic carotid disease in the population based on a random sample of patients who have undergone the ultrasound examination of the blood vessels of the neck. Furhtermore, the aitm is to determine the influence of age and gender on the frequency of asymptomatic carotid disease.

\section{Patients and methods}

This prospective study was conducted on the whole teritory of the Republic of Srpska. From 2012 to 2014, 20 240 patients were tested. There were 12797 (63.23\%) females and $7443(36.77 \%)$ males. All respondents who had asymptomatic stroke (AS) and transient ischemic attack (TIA) were not included in the project. Before the examination, each patient completed standardized questionnaire with data on marital status, education, personal and family history of previous stroke or TIA, heart disease, diabetes, hypertension, smoking and alcohol. After completing the questionnaire, the ultrasound examination of the blood vessels of the neck on both sides was done. All the procedures were standardized and performed by particularly trained researchers.

Ultrasound examination was performed in patients in the supine position - on the back. This way we were able to review the common carotid artery, bifurcation and the internal and external carotid artery in all patients. Ultrasound machine vivid 5 with a probe of $7 \mathrm{MHz}$ was used. IMK was measured on the basis of the adopted IMK definitions, and, if it was greater than $1 \mathrm{~mm}$, it was indicated as pathological. In the case of the plaque occurrence, the same was measured according to NASCET criteria.

\section{Results}

During three-year period, 20240 patients were examined - there were 12797 (63.23\%) females and 7443 (36.77\%) males. The youngest respondent was 18 year-old (both genders), while the eldest respondent, a female, was 93 years old (Table 1.).

Table 1. Age of the respondents according to gender

\begin{tabular}{lccccccc}
\hline Gender & $N$ & $\begin{array}{c}\text { Mini- } \\
\text { mum }\end{array}$ & $\begin{array}{c}\text { Maxi- } \\
\text { mum }\end{array}$ & Range Median & Mean & $\begin{array}{c}\text { Std. } \\
\text { Dev. }\end{array}$ \\
\hline Male & 7443 & 18 & 90 & 72 & 59.00 & 57.36 & 12.437 \\
Female & 12797 & 18 & 93 & 75 & 56.00 & 55.25 & 11.722 \\
Total & 20240 & 18 & 93 & 75 & 57.00 & 56.03 & 12.033 \\
\hline
\end{tabular}


By using the Mann-Whitney $\mathrm{U}$ test, there was a highly, statistically significant difference $(\mathrm{z}=-13.368, \mathrm{p}=0.000)$ in the age of the respondents in relation to the gender of the respondents.

Bearing in mind that $63.23 \%$ of the examined respondents were female and observing the age of the respondents according to groups, it was noticed that the female respondents were over-represented in the following age groups: 21 to 30 years (63.25\%), 31 to 40 years (65.40\%), 41 to 50 years $(68.67 \%)$ and 51 to 60 years $(66.27 \%)$. The degree of stenosis was present from o to $100 \%$ (both sexes). The average stenosis of the respondents was $18.36 \%$ (stenosis in females was on average $3.92 \%$ lower, that is, $16.92 \%$ when compared to males - $20.84 \%$ ). Overall median was $16 \%$ ( $15 \%$ in females and it decreased by $5 \%$ when compared to males - 20\%).

By using the Mann-Whitney U test, there was a highly statistically significant difference in the degree of stenosis in females ( $\mathrm{Md}=15.00, \mathrm{~N}=12797)$ and males $(\mathrm{Md}=20.00$, $\mathrm{N}=7443) ; \mathrm{z}=-19147, \mathrm{p}=0.000$. The examination of the degree of stenosis of the carotid basin in groups showed that the majority of patients (11 747 or $58.0 \%$ ) referred to the group of o\% to $19 \%$ of blockage, out of which 3716 (49.9\% of all male respondents) were males and 8031 (62.8\% of all female respondents) females. Based on frequency, the succeeding group was that of $20 \%$ to $49 \%$ of blockage $7740(38.2 \%)$ patients, that is, 3315 males $(44.5 \%$ of all male respondents) and 4425 females (34.6\% of all female respondents).

The degree of stenosis of the carotid area less than 50\% occurred in a total of 19487 (96.3\%) patients, 7031 males (94.5\% of all male respondents) and 12456 females (97.3\% of all female respondents). Over $50 \%$ of blockage occurred in $753(3.7 \%)$ respondents, i.e. 412 males $(5.5 \%$ of all male respondents) and 341 females (2.7\% of all female respondents) - Table 2.

Table 2. The degree of stenosis/group according to gender

\begin{tabular}{|c|c|c|c|c|c|}
\hline \multirow{2}{*}{\multicolumn{2}{|c|}{$\begin{array}{l}\text { The presentage of } \\
\text { stenosis /groups/ } \\
\text { cartoid artery }\end{array}$}} & & \multicolumn{2}{|c|}{ Gender } & \multirow[b]{2}{*}{ Total } \\
\hline & & & Male & Female & \\
\hline \multirow{2}{*}{\multicolumn{2}{|c|}{$0-19 \%$}} & $\mathrm{~N}$ & 3716 & 8031 & 11747 \\
\hline & & & $49.9 \%$ & $62.8 \%$ & $58.0 \%$ \\
\hline \multirow{2}{*}{\multicolumn{2}{|c|}{$20-49 \%$}} & $\mathrm{~N}$ & 3315 & 4425 & 7740 \\
\hline & & & $44.5 \%$ & $34.6 \%$ & $38.2 \%$ \\
\hline \multirow{2}{*}{\multicolumn{2}{|c|}{$50-69 \%$}} & $\mathrm{~N}$ & 293 & 257 & 550 \\
\hline & & & $3.9 \%$ & $2.0 \%$ & $2.7 \%$ \\
\hline \multirow{2}{*}{\multicolumn{2}{|c|}{$70-99 \%$}} & $\mathrm{~N}$ & 84 & 62 & 146 \\
\hline & & & $1.1 \%$ & $0.5 \%$ & $0.7 \%$ \\
\hline \multirow{2}{*}{\multicolumn{2}{|c|}{$100 \%$}} & $\mathrm{~N}$ & 35 & 22 & 57 \\
\hline & & & $0.5 \%$ & $0.2 \%$ & $0.3 \%$ \\
\hline \multirow{2}{*}{\multicolumn{2}{|c|}{ Total }} & $\mathrm{N}$ & 7443 & 12797 & 20240 \\
\hline & & $00.0 \%$ & $100.0 \%$ & $100.0 \%$ & \\
\hline
\end{tabular}

Considering the presence of stenosis / group / according to gender, a greater presence of low levels of stenosis in females was evident $(68.37 \%$ in the presence of stenosis from $0 \%$ to $19 \%$, and $57.17 \%$ in the presence of stenosis of $20 \%$ to $49 \%$ ). In the presence of stenosis, more than $50 \%$ higher prevalence was in males $53.27 \%$ in the presence of stenosis of $50 \%$ to $69 \%, 57.53 \%$ in the presence of stenosis from $70 \%$ to $99 \%$, and in the occlusion $-61.40 \%$ ).

At the percentage of stenosis from $0 \%$ to $19 \%$, by testing all the patients, there was a highly statistically significant difference $(\mathrm{p}=0.000)$ of the presence of stenosis in relation to gender (greater representation in female respondents). By monitoring the age groups in relation to gender, there was highly statistically significant difference in the following age groups - from 41 to 50 years (higher prevalence in females, $\mathrm{p}=0.000$ ); from 51 to 60 years (higher prevalence in females, $\mathrm{p}=0.000$ ) and from 71 to 80 years (higher prevalence in males, $\mathrm{p}=0.001$ ). However, there was a statistically significant difference in the following age groups - from 31 to 40 years (higher prevalence in females, $\mathrm{p}=0.020$ ); from 61 to 70 years (higher prevalence in females, $p=0.013$ ) and more than 80 year (higher prevalence in males, $\mathrm{p}=0.030$ ). (Table 3.).

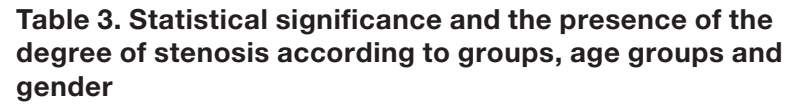

\begin{tabular}{|c|c|c|c|c|c|}
\hline \multirow{2}{*}{\multicolumn{2}{|c|}{$\begin{array}{l}\text { Age groups } \\
\text { The percentage of } \\
\text { stenosis }\end{array}$}} & \multicolumn{2}{|c|}{ Gender } & \multirow[b]{2}{*}{ Total } & \multirow[b]{2}{*}{$\mathrm{p}$} \\
\hline & & male & female & & \\
\hline$<=20$ & $0-19 \%$ & $12 / 11 /$ & $18 / 19 /$ & 30 & 0.714 \\
\hline $21-30$ & $0-19 \%$ & $190 / 190 /$ & $327 / 327 /$ & 517 & 0.993 \\
\hline \multirow[t]{3}{*}{$31-40$} & $0-19 \%$ & $600 / 647 /$ & $1158 / 1111 /$ & 1758 & $0.020^{*}$ \\
\hline & $20-49 \%$ & $21 / 14 /$ & $16 / 23 /$ & 37 & $0.012^{\star}$ \\
\hline & Total & $621 / 661 /$ & $1174 / 1134 /$ & 1795 & 0.056 \\
\hline \multirow[t]{6}{*}{$41-50$} & $0-19 \%$ & $877 / 1086 /$ & $2075 / 1866 /$ & 2952 & $0.000^{\star \star}$ \\
\hline & $20-49 \%$ & $202 / 184 /$ & $299 / 317 /$ & 501 & 0.102 \\
\hline & $50-69 \%$ & 4 & 1 & 5 & \\
\hline & $70-99 \%$ & 1 & 0 & 1 & \\
\hline & $100 \%$ & 0 & 1 & 1 & \\
\hline & Total & $1084 / 1272 /$ & $2376 / 2188 /$ & 3460 & $0.000^{\star \star}$ \\
\hline \multirow[t]{6}{*}{$51-60$} & $0-19 \%$ & $1248 / 1580 /$ & 3046 /2714/ & 4294 & $0.000^{\star \star}$ \\
\hline & $20-49 \%$ & 1048 /952/ & $1538 / 1634 /$ & 2586 & $0.000^{\star \star}$ \\
\hline & $50-69 \%$ & $51 / 35 /$ & $45 / 61 /$ & 96 & $0.001^{\star \star}$ \\
\hline & $70-99 \%$ & $12 / 8 /$ & $10 / 14 /$ & 22 & 0.084 \\
\hline & $100 \%$ & $4 / 3 /$ & $4 / 5 /$ & 8 & 0.438 \\
\hline & Total & $2363 / 2576 /$ & $4643 / 4430 /$ & 7006 & $0.000^{\star \star}$ \\
\hline \multirow[t]{6}{*}{$61-70$} & $0-19 \%$ & 633 /685/ & $1228 / 1176 /$ & 1861 & $0.013^{*}$ \\
\hline & $20-49 \%$ & $1292 / 1100 /$ & $1697 / 1889 /$ & 2989 & $0.000^{\star *}$ \\
\hline & $50-69 \%$ & $123 / 82 /$ & $99 / 140 /$ & 222 & $0.000^{\star *}$ \\
\hline & $70-99 \%$ & $36 / 21 /$ & $21 / 36 /$ & 57 & $0.000^{\star \star}$ \\
\hline & $100 \%$ & $19 / 10 /$ & $8 / 17 /$ & 27 & $0.000^{\star *}$ \\
\hline & Total & $2103 / 1896$ & 3053 /3260/ & 5156 & $0.000^{\star *}$ \\
\hline
\end{tabular}




\begin{tabular}{|c|c|c|c|c|c|}
\hline \multirow{2}{*}{\multicolumn{2}{|c|}{$\begin{array}{l}\text { Age groups } \\
\text { The percentage of } \\
\text { stenosis }\end{array}$}} & \multicolumn{2}{|c|}{ Gender } & \multirow[b]{2}{*}{ Total } & \multirow[b]{2}{*}{$p$} \\
\hline & & male & female & & \\
\hline \multirow[t]{6}{*}{$71-80$} & $0-19 \%$ & $143 / 115 /$ & $170 / 198 /$ & 313 & $0.001^{\star \star}$ \\
\hline & $20-49 \%$ & $659 / 5$ & $923 /$ & 1460 & $0.000^{\star \star}$ \\
\hline & $50-69 \%$ & $100 / 74 /$ & $101 / 127 /$ & 201 & $0.000^{\star \star}$ \\
\hline & $70-99 \%$ & $31 / 21 /$ & $27 / 37 /$ & 58 & $0.008^{\star *}$ \\
\hline & $100 \%$ & $10 / 6 /$ & $7 / 11 /$ & 17 & \\
\hline & $\overline{T \text { Total }}$ & $943 / 753 /$ & $1106 / 1296 /$ & 2049 & $0.000^{\star *}$ \\
\hline \multirow[t]{6}{*}{$>80$} & $0-19 \%$ & $13 / 8 /$ & $9 / 14 /$ & 22 & $0.030^{*}$ \\
\hline & $20-49 \%$ & $93 / 61 /$ & $74 / 106 /$ & 167 & $0.000^{\star \star}$ \\
\hline & $50-69 \%$ & $15 / 10 /$ & $11 / 16 /$ & 26 & $0.027^{\star}$ \\
\hline & $70-99 \%$ & 4 & 4 & 8 & \\
\hline & $100 \%$ & 2 & 2 & 4 & \\
\hline & Total & $127 / 83 /$ & $100 / 144 /$ & 227 & $0.000^{\star \star}$ \\
\hline \multirow[t]{6}{*}{ Total } & $0-19 \%$ & $3716 / 4323 /$ & $8031 / 7424 /$ & 11747 & $0.000^{\star *}$ \\
\hline & $20-49 \%$ & $3315 / 2848 /$ & $4425 / 4892 /$ & 7740 & $0.000^{\star \star}$ \\
\hline & $50-69 \%$ & $293 / 202 /$ & $257 / 348 /$ & 550 & $0.000^{\star \star}$ \\
\hline & $70-99 \%$ & $84 / 54 /$ & $62 / 92 /$ & 146 & $0.000^{\star *}$ \\
\hline & $100 \%$ & $35 / 21 /$ & 22 /36/ & 57 & $0.000^{\star \star}$ \\
\hline & Total & 7443 & 12797 & 20240 & \\
\hline
\end{tabular}

By monitoring all the patients, in the case of the degree of stenosis from 20 to $49 \%$, there was a highly statistically significant difference $(\mathrm{p}=0.000)$ in the presence of stenosis in relation to gender (greater representation in male respondents). By monitoring the age groups with respect to gender, there was highly statistically significant difference for all age groups over 50 years (higher prevalence in males, $\mathrm{p}=0.000$ ), as well as statistically significant difference in the age groups from 31 to 40 years (higher prevalence in males, $\mathrm{p}=$ o.012) (Table 3.).

By monitoring all the patients, in the case of the degree of stenosis of $50 \%$ to $69 \%$, there was a highly statistically significant difference $(\mathrm{p}=0.000)$ in the presence of stenosis in relation to gender (higher representation in male respondents). By monitoring the age groups with respect to gender, there was a highly statistically significant difference in the age groups from 51 to 60 years (higher prevalence in males, $\mathrm{p}=0.001$ ); from 61 to 70 years (higher prevalence in males, $p=0.000$ ), and from 71 to 80 years (higher prevalence in males, $p=0.000$ ), as well as a statistically significant difference in the age group above 40 years old (higher prevalence in males, $\mathrm{p}=0.027$ ) (Table 3 ).

By monitoring all the patients, in the case of the degree of stenosis of $70 \%$ to $99 \%$, there was a highly statistically significant difference $(\mathrm{p}=0.000)$ in presence of stenosis in relation to gender (higher representation in male respondents). Throughout monitoring the age groups with respect to gender, a highly statistically significant difference was noticed in the following age groups: from 61 to 70 years (higher prevalence in males, $\mathrm{p}=0.000$ ); from 71 to 80 years (higher prevalence in males, $\mathrm{p}=0.008$ ).
In the case of complete blockage of the carotid arteries (occlusion) and throughout monitoring all the patients, there was a highly statistically significant difference $(\mathrm{p}=$ o.0oo) in the presence of occlusion in relation to gender (higher representation in male respondents). Throughout monitoring the age groups with respect to gender, a highly statistically significant difference was noticed for the age group of 61 to 70 years (higher prevalence in males, $\mathrm{p}=$ 0.000).

\section{Figure 1. The statistical significance of the presence of} stenosis according to groups, age groups and gender

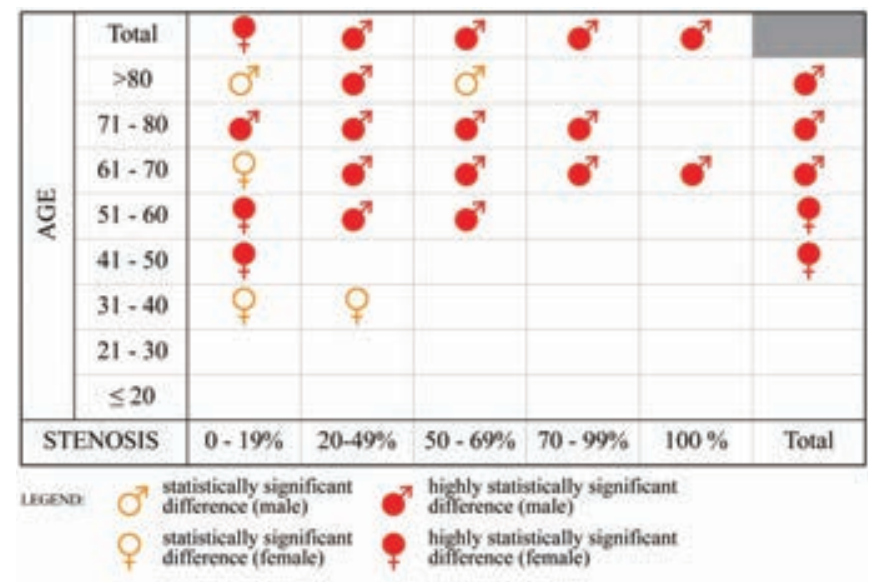

Regarding the lower degrees of stenosis, more than expected number of cases occurred in females, while at the higher degree of stenosis, more than expected number of cases occurred in males, as well as in age groups - at lower age groups (younger), more than expected number of cases occurred in females, and in the higher age groups (older), more than expected number of cases occurred in males. (Figure 1.).

\section{Discussion}

Stroke is the leading cause of death and hospitalization in both males and females in almost every European country and the third cause of death in the United States. Carotid disease is one of the most important causes of stroke. ${ }^{1-4}$ Studies have shown that the annual risk of stroke in patients with asymptomatic carotid disease varies from 2 to $5 \%$ in the case of patients with severe asymptomatic carotid stenosis. The importance of carotid atherosclerosis is widely recognized because of its correlation with coronary atherosclerosis and other cardiovascular risk factors. ${ }^{4-7}$

The prevalence of severe stenosis was noticed in males, more than in females, at the age of 70 . In the case of patients older than 70 years, the difference is higher. The prevalence of males in that age was $12.5 \%$ and of females $6.9 \%$. In Beks and associates' study, ${ }^{22}$ the prevalence of any detectable lesions in males was $25.4 \%$, and $26.6 \%$ in females. The degree of stenosis increased with age. ${ }^{22}$. The 
analysis of the frequency of carotid disease by gender showed that before the sixth decade of life, there was almost doubled prevalence of carotid disease in females than in males. However, after the seventh decade, the difference was almost balanced. ${ }^{22}$

In Fabris and associates' study ${ }^{18}$, on the sample of 457 patients aged 18-97 years, a positive findings of the existence of atherosclerotic plaques in 178 patients, or $38.9 \%$ of the patients were noticed. According to this author, the prevalence of carotid disease was $45.4 \%$ in males and $32.3 \%$ in females. ${ }^{18}$ Also, this author recognized a higher prevalence in males than in females which increased with age (prevalence in the group of patients 65-74 years was $59.9 \%$, and in the group over 75 years, $76.7 \%) .{ }^{18}$ The abovementioned author also recognized post-menopausal hormonal changes that led to increased atherosclerosis in females as the most probable cause for that phenomenon. ${ }^{18}$ Not only did the frequency, but the severity of carotid disease progressed with age as well. ${ }^{18}$ Average percentage of stenosis at the point of maximum stenosis was $9.1 \%$ in the age group from 45 to 64 years, $17.3 \%$ in the age group of $65-74$ years and $27.1 \%$ in patients aged over 75 years. ${ }^{18}$

Similar results were obtained in our study. The average stenosis of all the respondents was $18.36 \%$ (stenosis was $3.92 \%$ less in females and was $16.92 \%$, when compared to males - 20.84\%). Considering the presence of stenosis / group / according to gender, a greater presence of low levels of stenosis in females was evident. In the presence of stenosis, more than 50\% higher prevalence was in males. The presence of significant stenosing plaque in the carotid increased in accordance with the age.

\section{Conclusion}

The incidence of moderately severe carotid artery stenosis increases with age, more frequently in males than in females women.

By establishing the ultrasound examination as required screening method for patients of certain age range, the occurrence of stroke in elderly people could be prevented.

\section{References}

1. Primatesta $\mathrm{P}$, Allender S, Ciccarelli P, Doring A, Graff-Iversen S, Holub J, Panico S, Trichopoulou A, Verschuren WM. Cardiovascular surveys: manual of operations. Eur $J$ Cardiovasc Prev Rehabil. 2007; 14: S43-S61

2. Thom T, Haase N, Rosamond W, Howard VJ, Rumsfeld J, Manolio T, Zheng ZJ, Flegal K, O'Donnell C, Kittner S, Lloyd-Jones D, Goff DC Jr, Hong Y, Adams R, Friday G, Furie K, Gorelick P, Kissela B, Marler J, Meigs J, Roger V, Sidney S, Sorlie P, Steinberger J, Wasserthiel-Smoller S, Wilson M, Wolf P. Heart disease and stroke statistics-2006 update: a report from the American Heart Association Statistics Committee and Stroke Statistics Subcommittee.Circulation. 2006; 113: e85-e151
3. Autret A, Pourcelot L, Saudeau D, Marchal C, Bertrand P, de Boisvilliers S. Stroke risk in patients with carotid stenosis. Lancet. 1987; 1: 888-890.

4. Inzitari D, Eliasziw M, Gates P, Sharpe BL, Chan RK, Meldrum HE, Barnett HJ. The causes and risk of stroke in patients with asymptomatic internal-carotid-artery stenosis. North American Symptomatic Carotid Endarterectomy Trial Collaborators. N Engl J Med. 2000; 342: 1693-1700.

5. Hennerici M, Hulsbomer HB, Hefter H, Lammerts D, Rautenberg W. Natural history of asymptomatic extracranial arterial disease: results of a long-term prospective study. Brain. 1987; 110: 777791.

6. Norris JW, Zhu CZ, Bornstein NM, Chambers BR. Vascular risks of asymptomatic carotid stenosis. Stroke. 1991; 22: 1485-1490.

7. O’Holleran LW, Kennelly MM, McClurken M, Johnson JM. Natural history of asymptomatic carotid plaque: five year follow-up study. Am J Surg. 1987;154: 659-662.

8. Chan A, Beach KW, Martin DC, Strandness DE Jr. Carotid artery disease in NIDDM diabetes. Diabetes Care. 1983; 6: 562-569.

9. van Merode T, Hick P, Hoeks PG, Reneman RS. Serum HDL/ total cholesterol ratio and blood pressure in asymptomatic atherosclerotic lesions of the cervical carotid arteries in men. Stroke. 1985; 16: 34-38

10. Josse MO, Touboul PJ, Mas JL, Laplane D, Bousser MG. Prevalence of asymptomatic internal carotid artery stenosis. Neuroepidemiology. 1987; 6:150-152.

11. Colgan MP, Strode GR, Sommer JD, Gibbs JL, Sumner DS. Prevalence of asymptomatic carotid disease: results of duplex scanning in 348 unselected volunteers. $J$ Vasc Surg. 1988; 8: 674-678.

12. Langsfeld M, Lusby RJ. The spectrum of carotid artery disease in asymptomatic patients. J Cardiovasc Surg. 1988; 29: 687-691.

13. Bots ML, Breslau PJ, Briet E, de Bruyn AM, van Vliet HH, van den Ouweland FA, de Jong PT, Hofman A, Grobbee DE. Cardiovascular determinants of carotid artery disease: the Rotterdam Elderly Study. Hypertension. 1992; 19:717-720.

14. O'Leary DH, Anderson KM, Wolf PA, Evans JC, Poehlman HW. Cholesterol and carotid atherosclerosis in older persons: the Framingham Study. Ann Epidemiol. 1992; 2: 147-153.

15. O’Leary DH, Polak JF, Kronmal RA, Kittner SJ, Bond MG, Wolfson SK Jr, Bommer W, Price TR, Gardin JM, Savage PJ. Distribution and correlates of sonographically detected carotid artery disease in the Cardiovascular Health Study: the CHS Collaborative Research Group. Stroke. 1992; 23: 1752-1760

16. Pujia A, Rubba P, Spencer MP. Prevalence of extracranial carotid artery disease detectable by echo-Doppler in an elderly population. Stroke. 1992;23: 818-822

17. Sutton-Tyrrell K, Alcorn HG, Wolfson SK Jr, Kelsey SF, Kuller LH. Predictors of carotid stenosis in older adults with and without isolated systolic hypertension. Stroke. 1993; 24: 355-361.

18. Fabris F, Zanocchi M, Bo M, Fonte G, Poli L, Bergoglio I, Ferrario E, Pernigotti L. Carotid plaque, aging, and risk factors: a study of 457 subjects. Stroke.1994; 25: 1133-1140.

19. Lindgren A, Roijer A, Norrving B, Wallin L, Eskilsson J, Johansson BB. Carotid artery and heart disease in subtypes of cerebral infarction. Stroke. 1994; 25:2356-2362.

20. Pascazio L, Sabbadini G, Rieppi S, Curri G. Carotid and lower limbs arterial atheromasic disease in elderly patients with hy- 
pertensive left ventricular hypertrophy. Cardiovascular Imaging. 1994; 6: 45-49.

21. Harer C, Gusev EI. Asymptomatic cervical artery stenoses in Moscow. Acta Neurol Scand. 1996; 93: 286-290
22. Beks PH, Mackaay AJ, de Vries H, de Neeling JN, Bouter LM, Heine RJ. Carotid artery stenosis is related to blood glucose level in an elderly Caucasian population: the Hoorn Study. Diabetologia. 1997; 40: 290-298.

\section{Uticaj životnog doba i pola na karotidnu asimptomatsku bolest}

\section{SAŽETAK}

Uvod: Moždani udar je jedna od najtežih i najčešćih bolesti savremenog čovjeka. Prevencije je potrebna za detekciju osoba koje imaju faktore rizika za nastanak moždanog udara.

Cilj rada: Utvrditi učestalost asimptomatske karotidne bolesti kod osoba različite životne dobi.

Ispitanici i metode: Projektom je obuhvaćen dio stanovništva koje pripada rizičnim grupama za dobijanje moždanog udara sa područja Republike Srpske. Pregledano je 20240 pacijenata - 12797 (63,23\%) ženskog i 7443 (36,77\%) muškog pola.

Kreiran je Protokol studije i izrađeni su adekvatni softverski proizvodi kao podrška svih faza realizacije projekta: priprema reklamnih materijala, zakazivanje pregleda, izrada aplikacije namijenjene ljekarima i medicinskim sestrama za evidentiranje podataka o pacijentima, izvještavanje, analiza i zaključivanje.Nakon završetka projekta statistički su obrađeni podaci i izvršena je analiza dobijenih rezultata.

Diskusija: Ultrazvučnim pregledom krvnih sudova vrata i glave, otkrivene su patološke promjene u navedenim krvnim sudovima, određen jestepen suženja krvnih sudova, primijenjene su adekvatne mjere i tretman radi sprečavanja napredovanja istih i onemogućavanja javljanja moždanog udara.Na osnovu dobijenih podataka zaključeno je da je životna dob jedna od najznačajnijih predisponirajućih faktora za razvoj karotidne asimptomatske bolesti. Takođe je primjećeno da su žene sklonije razvoju karotidne asimptomatske bolesti od muškaraca.

Zaključak: Prosječnastenozasvihispitanikaje18,36\% (kod ženskogpolastenozajeprosječnomanja 3,92\% i iznosila je 16,92\%, uodnosunamuškipol-20,84\%). Ukupnamedijanaje 16\% (kod ženaje 15\% i za 5\% je manja u odnosu na muškarce - 20\%).

Ključne riječi: ultrazvučni pregled krvnihsudovavrataiglave, prevencija,starost, pol 